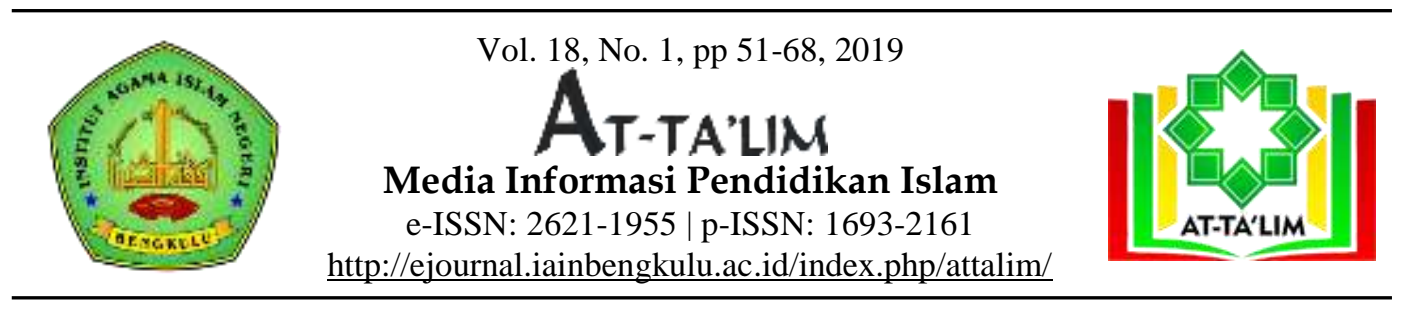

\title{
THE USE OF PICTURE MEDIA TO ENHANCE STUDENTS' WRITING ABILITY OF RECOUNT TEXT AT MTS N 1 OF BENGKULU CITY, BENGKULU
}

\author{
DEDI EFRIZAL ${ }^{1}$ \\ 1 efrizaldedi279@gmail.com \\ ${ }^{1}$ dosen Institut Agama Islam Negeri (IAIN) Bengkulu \\ Jl. Raden Fatah Kota Bengkulu, Indonesia. \\ Received: March 13 $2019 \quad$ Accepted : May 30th $2019 \quad$ Published June $25^{\text {th }} 2019$
}

Abstract: - The Use of Picture Media to Enhance Students' Writing Ability of

Recount Text at MTs N 1 of Bengkulu City, Bengkulu. This study was carried out to improve the students' writing ability through Pictures media in Second Year Students at Mts N 01 of Bengkulu in academic year 2018-2019. The subjects of this study were consisted of 42 students. The method used in this study was Classroom Action Research (CAR). The Clasroom Action Research design applied in this study was a collaborative classroom action research. It mean that the researcher collaborated with the English teacher of Mts N 01 of Bengkulu as an observer and collaborator. The study was carried out in three cycles. Each cycles consisted of three meetings. The data were gathered in this study through field notes, and test. The result of the study showed that there was improvement of students' writing ability. Most of the students gradually gained good scores at the end of each cycles. The score of Minimum Mastery Criterion- Kriteria Ketuntasan Minimal (KKM) of English subject was 70 (seventy). In In cycle, the result of the students score was poor. In cycle 2 the result of the students score has some progresses, and in the cycle 3 the result of the students score has improve effectively than action in cycle before were the mean score of students was in 75 (Good). In addition, there was a positive response from the English Teacher about implementing the action. In conclusion Pictures media could solve the students' problems and improve their writing ability.

Keyword: Picture Media, Students' Writing Ability, Recount Text

Abstrak: Penggunaan Media Gambar untuk Meningkatkan Kemampuan Menulis
Teks Recount Siswa di MTs N 1 Kota Bengkulu, Bengkulu. Penelitian ini
dilakukan untuk meningkatkan kemampuan menulis siswa melalui media Pictures pada
Siswa Kelas Dua di Mts N 01 Bengkulu pada tahun akademik 2018-2019. Subjek
penelitian ini terdiri dari 42 siswa. Metode yang digunakan dalam penelitian ini adalah
Penelitian Tindakan Kelas (PTK). Desain Penelitian Tindakan Clasroom yang
diterapkan dalam penelitian ini adalah penelitian tindakan kelas kolaboratif. Ini berarti
bahwa peneliti berkolaborasi dengan guru bahasa Inggris Mts N 01 dari Bengkulu
sebagai pengamat dan kolaborator. Penelitian dilakukan dalam tiga siklus. Setiap siklus
terdiri dari tiga pertemuan. Data dikumpulkan dalam penelitian ini melalui catatan
lapangan, dan tes. Hasil penelitian menunjukkan bahwa ada peningkatan kemampuan
menulis siswa. Sebagian besar siswa secara bertahap memperoleh skor bagus di akhir
setiap siklus. Skor Kriteria Penguasaan Minimum- Kriteria Ketuntasan Minimal 
(KKM) mata pelajaran bahasa Inggris adalah 70 (tujuh puluh). Dalam siklus, hasil nilai siswa buruk. Pada siklus 2 hasil skor siswa mengalami beberapa kemajuan, dan pada siklus 3 hasil skor siswa telah meningkat secara efektif daripada tindakan dalam siklus sebelum skor rata-rata siswa berada di 75 (Baik). Selain itu, ada tanggapan positif dari Guru Bahasa Inggris tentang penerapan tindakan. Kesimpulannya, media Pictures dapat menyelesaikan masalah siswa dan meningkatkan kemampuan menulis mereka.

Kata Kunci: Media Gambar, Kemampuan Menulis Siswa, Menulis Ulang Teks

\section{To cite this article:}

Efrizal, D (2019). The Use of Picture Media to Enhance Students' Writing Ability of Recount Text at MTs N 1 of Bengkulu City, Bengkulu. At-Ta'lim: Media Informasi Pendidikan Islam, 18(1), 51-68.

\section{A. INTRODUCTION}

In Indonesia, English is Implemented as a foreign language. Indonesian students learn English as a foreign language because it becomes a subject of the lesson in the school. EFL described situations where students were learning English in order to use it with any other English speaker in the world. In this case, students know well about the sentence patterns and diction and they should be implemented in four skills (Harmer, 2007: 19).

The researcher is focusing her research on writing because writing is one of the four language skills that play a very important role in second language learning. Writing skill is more complex and difficult to teach, requiring the mastery not only the grammatical and theoretically devices but also the conceptual and judgment.

One of the visual aids that can be used in learning writing is pictures. The study is the implementation of writing recont text by using pictures especially in writing recount text. The strategy is selected since it can guide the students to generate idea into a meaningful composition. Picturess usually capture past events and picturess surely can help students remember details about people, places, and events. In short, they can be powerful sources of text. Besides, a pictures is worth a thousand 
words because one picture can tell the students something even has sequences to study behind it. Pictures give chance to student to learn from primary sources catches students'interest, they experience the excitement of partici- pating in detective work, and they discover that they already have the skills and knowledge to learn from these items (Hatcher, 1987: 11).

Based on the observation, there weresome problems found in Mts $\mathrm{N}$ 01 of Bengkulu. First, the students' writing problems were related to the processes of developing ideain writing. It could be seen in the class when they asked by the teacher to write a text, they looked very confused to write a text. Second, some students looked not enthusiastic to write a text based on the teacher's instruction. They looked not enthusiastic because they had no idea on what they want to write in their worksheet. In addition, it could be seen in the result of the lesson,most of the students got bad score. Third, the students have less vocabulary so they get difficulties to write the text. Fourth, The students motivation is low. It can be seenwhen teacher give many task, the students cannot finish the task. Beside that, they did not pay attention to the teacher instuctions, they were not confident asking to the teacher when they found the difficulties in writing . Fifth, the facilites such as teaching learning book is less. Sixth, the teacher has monoton technique because there were not any variation activities of learning writting. The last,there wasn't learning media so it make students bored to write the text in learning writing.

Therefore, based on the usefulness of the picturess, the researcher chooses picturess as media or technique to improve writing recount text. It means that there is a significant relationship between writing recount text and using pictures, because recount text is one of the story genres.The focus of the research is that pictures technique could give the students new experience in learning writing. Hopefully the students will be interested and more active when teachers teach writing. 


\section{Recount Text}

\section{a) The Concept of Recount Text}

According to Wadiman (2008:61), recount text is a text that tell the reader about one story, action or activity. It goal is to entertain or inform the reader. A recount is the unfolding of a sequence of events overtimes. It is used to tell past events for the purpose of informing or entertaining. Its focus is on a sequence of events.It is generally begun with an orientation.Then, the recount unfolds with a series of events (ordered in a chronological sequence). At various stages, there may be some personal comments on the incident. We call it re-orientation.

According to Anderson a recount is speaking or writing about past events or a piece of text that retells past events, usually in the order which they happened. Recount text means the form of the text telling about someone experience in the past that used in curriculum 2004, there for the experience of the readers themselves, such as theiradventure and their day's activities (Anderson, K. 1997: 48).

According to knapp (2005:224) recount text, basically is written out to make a report about and experience of a series of related event. A recount is written out to inform an event or to entertain people.

Recount is to tell "what happened". A recount text has a social function. The purpose of a social function is to retell an event with a purpose to inform or entertain the readers (Siahaan and Shinoda, 2008: 9). Recount tells a series of events and evaluate their significance in some way. It is also to give audience a descriptions of what occurred and when it occurred. The story recount has expressions of attitude and feeling, usually made by narrator about the events.

From all explaination above, it conclude that, perception recount text is a text tell about story someone in the past, in writing recount text past events or a piece of text that retells past events,usually in the order which they happened, recount text also has a social function. 


\section{b) The Purpose of Recount}

Siahaan and Shinoda, Text A recount has social function. Recount "tell what happened". The purpose of a social recount is to document a series of events and evaluate their significance in some way. It is also to give the audience a descriptions of what occurred and when it occurred. The purpose of the literary / story recount is to tell a sequence of events so that it entertains. The story recount has expressions of attitude and feeling, usually made by narrator about the events (Sanggam Siahaan and Kisno Shinoda, 2008: 9).

\section{c) The Generic Structure of a Recount Text}

Recount beging by telling the reader who was involved, what happened where this even took place and when it happened. Recount explores the series of event which happened to participants. The event is the main element in composing recount text. The event are explained in chronological order based on time and place. According to Andersons of what occured and when it accored (Mark \& Kathy. 1997: 49).

A recount text consist of there parts : Orientation, Event, and Reriontation.

a) Orientation

Orientaition is introducing the partipants who involve in the story, the place where and the story happened and when the story happened Emilia

b) Event

Event is the main important activities or event that occurred in that story of text. Emilia state the function of event is the give sequence of events. It presents the event chronologically ( in order which they happened).

c) Reriontation

Reriontation is optional. It return the reader to the point of departure and sometimes the writen also give comment on the whole sequence of event described (Emilia. 2010: 9). 


\section{d) Types of Recount}

Text In exploring how text work (Derewinka, 1990: 15-17) there are three types of recount. They are:

\section{a. Personal Recount}

Personal recount is a recount that retelling of an activity that researcher or speaker has been personally involved in (e.g. oral anecdote, diary entry). Language features of personal recount are:

1). Use of first pronoun (I, we).

2). Personal responses to the events can be included, particularly at the end.

3). Details are often chosen to add interest or humor.

\section{b. Factual Recount Text}

Factual recount is a recount that recording the particulars of an accident. (E.g. report of a science experiment, police report,news report, historical recount). Language features of factual recount are:

1. Use of third person pronouns (he, she, it, they).

2. Details are usually selected to help the reader reconstruct the activity or incident accurately.

3. Sometimes the ending describes the outcome of the activity (e.g. in a science experiment).

4. Mention of personal feelings in probably not appropriate.

5. Details of time, place, and manner may be need to be precisely stated (e.g. at $2.35 \mathrm{pm}$, between John st, and Park rd, the mandrove at $80 \mathrm{kbp}$ ).

6. Descriptive details may also be required to provide precise information (e.g. a man with a red shirt, brown shoes and long his, weighing 75 kilos and approximately $189 \mathrm{~cm}$ tall).

7. The passive voice may be used (e.g. the breaker was filled with water). 
8. It maybe appropriate to include explanations and satisfactions.

\section{c. Imaginative Recount}

Imaginative recount is a recount that taking on an imaginary role and giving details events (e.g. a day in the life of a Roman Slave: how I invited...)

1. Verb use that varies from the usual past tense or that focuses on mental or sensing processes

2. Dialogue where the tense changes and reporting words may or may not be added to identify the speaker

3. Descriptive language that enhances or develops the story often through the use of imagery

4. A variety of linking words to do with time and events that are foreshadowed or reflected on so that the sequence changes.

Based on the types of recont text above, the researcher will use imaginative recount text as a instrument in this research. Because the researcher will give the students some photograph to make recount text.

\section{d. Constructing a Written Recount Text}

Board of studies (1998b:287) the steps for constructing of written recount text are:

1. The First paragraph that give background information about who, what, where and when. It is called on orientation.

2. A record of events usually recounted in chronological order, named; event 1 , event 2 , event 3 .

3. A personal comment and or evaluative remarks, which are interspersed throughout the record of events named evaluation. 
4. A reorientation which "rounds off "the sequences of events or retell about what happened in the end.

\section{6) Languages Features in a Recount Text}

Board of studies (1998b:287) the language features usually found in a recount:

a. Use of nouns and pronouns to identify people, animals or things involved.

b. Use of past action verbs to refer the events.

c. Use of past tense to located events in relation to speaker`s or researcher`s time.

d. Use conjunctions and time connectives to sequence the event.

e. Use of adverb and adverbial phrases to indicate place and time.

f. Use of adjectives to describe nouns

Andersons mention the languge features usually found in recount text are:

a) Proper noun identify those involve in the text.

b) Descriptive word to give detail about who, what, when, where and how.

c) The use of past tense to retells the eventd.

d) Words that show the order of events (for example : first, second, third, next, then, finally).

Wadiman points out that language features of recount text focuses on use noun or pronoun (i.e. I, a magazine) and uses past tense (i.e. I took, I saw) (Wadirman, A. 2008: 61).

Moreover, puguhyulianto the language features which are usually found in recount text are: introducing personal participant (i.e. I, my group, etc), use chronological connection (i.e. then, first, etc), simple past tense (i.e. he painted, she smiled, etc) (Puguhyulianto. 2011). 


\section{7) Significant of Lexical Grammatical Features}

In making of functional grammar, Board of studies (1998b:287) the significant common grammatical patterns of recount include:

a. Focus on specific participant.

b. Use of material process or action verb.

c. Circumstance of time and place.

d. Use past tense and focus on temporal sequences.

Based on explaination above, in writing there are some significant of lexical grammatical. First, focus on specific participant, the second, use of materialprocess or action verb, third, Circumstance of time and place. And the last, Use past tense and focus on temporal sequences.

\section{The Steps of Teaching Writing Recount Text Using Photograph}

According to Sarah hatcher (1987), the process of teaching with objects is quite simple, based on the basic steps which museum curators, folklorists, archaeologists, art historians, and other scholars use for learning from objects. Authorities on the topic use various terminology in their own fields, but all center on three basic elements: description, classification, and interpretation.

a) Description: What is this object?

Learners examine the object directly when compiling a description. A good first step is developing a complete description of the object's physical appearance. The major skill exercised and developed when describing the object is Observation based on the evidence of the senses.

What are the basic elements required in a description? Determining the material used to create the object is a vital component of description, and can lead to many kinds of inquiry. For instance, asking a basic question, "Are the materials natural or human made?" opens up the wide subject of how people and cultures relate to their natural environment. 
Other topics which can be explored in this stage are the object's use, method of manufacture, date, place of origin, and maker. Some of these characteristics may be suggested from examination of the object itself, while others will take research into other sources (books, catalogs, web sites, people more familiar with the item).

It is important to note that in addition to the evidence of the senses, students will be bringing their prior knowledge of materials and types of objects to their explorations. It is good to recognize this explicitly in the exercise. For instance, if students are compiling a written description of a wooden bowl, you might ask them to cite their evidence for each observation. If they state that the object is made of wood, ask, How do you know? They might answer, It feels like wood, or looks like wood, or sounds like wood when you tap it, or smells like wood. These replies can be followed up with questions about the general characteristics of wood to support their finding. Likewise if they call the item a bowl, ask them to support that finding. What is a bowl? Does this item have all the characteristics necessary in a bowl? Are there other items that have those same characteristics?

b) Classification: How does this object relate to others?

Classifications can be used to explore a multitude of questions: What value is placed on this object? Is its value due to materials, function, date, rarity, ownership history, place of origin, or religious associations? Does the object mean different things to different people?

The ability to compare and contrast is the central skill used in classification. Comparative analysis can be accomplished on a very simple level with younger students, and refined to much more detailed levels for older ones.

1) Compared to What?

The first question to answer in classification is, "Which objects are we using as our comparative set?" The answer will depend on your curriculum goals. If you are using objects to 
explore change over timein a history class, you will want to use a comparative base that includes items from different historical periods. If you are using objects in a lesson on cultural diversity, you will want to use objects from different cultures. In both of these cases, learning is helped by considering only a small range of objects. For instance, to explore changes in American life over the past 200 years, you might want to focus on two or three sorts of artifacts, such as items used in transportation, food preparation, and play(We'll explore how this can be done in the lesson plans.)

2) Classification Schemes

Another curriculum option is to examine classification itself. This exercise helps to develop critical thinking skills, because students have the opportunity to assess many different options and decide from among them. For instance, if the class is looking at a wide range of objects, such as things found at a garage sale, students can explore different ways of sorting the objects, such as by size, color, function, price, age, or state of repair. In the process of doing this, they will question the value of each form of classification. What questions can we answer after sorting the items by color? What different sorts of questions can we answer by sorting the objects according to their state of repair? Lesson 2 explores many issues associated with classification.

3) Selecting Criteria

Another process that uses critical thinking skills occurs in all forms of classification, no matter the curriculum goals or learning levels involved: determining the relevant criteria for classifying objects. This process requires that students weigh various factors and determine which are useful in answering the questions at hand. If students are examining change over time in automobile manufacture as part of a curriculum unit on changes in the American family during the 20th century, which attributes 
are important-size? shape? color? material? engine type? The use of classification in lessons, whether as the primary focus or as a means to an end, is a great opportunity to reinforce the notion that all research findings are shaped by the questions we ask.

c) Interpretation: What stories does this object tell?

Any one object can tell a great many stories-once again, this will depend on the questions you and your students ask. The most important concept in interpretation is context, the cultural setting of the object. Description and classification can be carried out with no actual knowledge of the cultural, environmental, social, or other contexts of an object, but for interpretation this information is essential. Seeking this knowledge is itself a rewarding activity for students whose curiosity has been awakened by an object, and it is a splendid opportunity for teaching higher levels of investigative skills.

The classic journalist's questions - what, who, where, when, and how? - are ideal first steps in this kind of research. Lesson three uses ordinary spoons in an example of this kind of inquiry, and also introduces the ultimate goal of interpretation:

answering the question, "Why?"(Why is the spoon shaped this way? Why is it made from wood? Why is it used in this way? Why is it used here?). As the word "interpretation"implies, explanations of "why" are never absolute. Different students or groups of students will arrive at different interpretations of an object's meaning. Of course, this can give rise to discussion of the various interpretations, with attendant opportunities for learning about listening skills and respect for diverse views (Hatcher, 1987: 11).

\section{B. METHOD}

The objective of this research is to implement pictures media to solve students' problems and improve students' writing ability for Second Year Students at Mts N 01 of Bengkulu in academic year 2018/2019. This 
research using method Classroom Action Research. The data is analyzed by using percentages. The procedures of this research were preassessment, cycle I, cycle II, and cycle III. Each cycle consists of planning, acting, observing and reflecting and evaluating. At first syntax, the researcher collected individual score at the end of cycles by giving test to the students. And then, researcher counted the students score into percentages by following students' score interval.

\section{RESULTS AND DISCUSSION}

1. Results

a. Cycle I

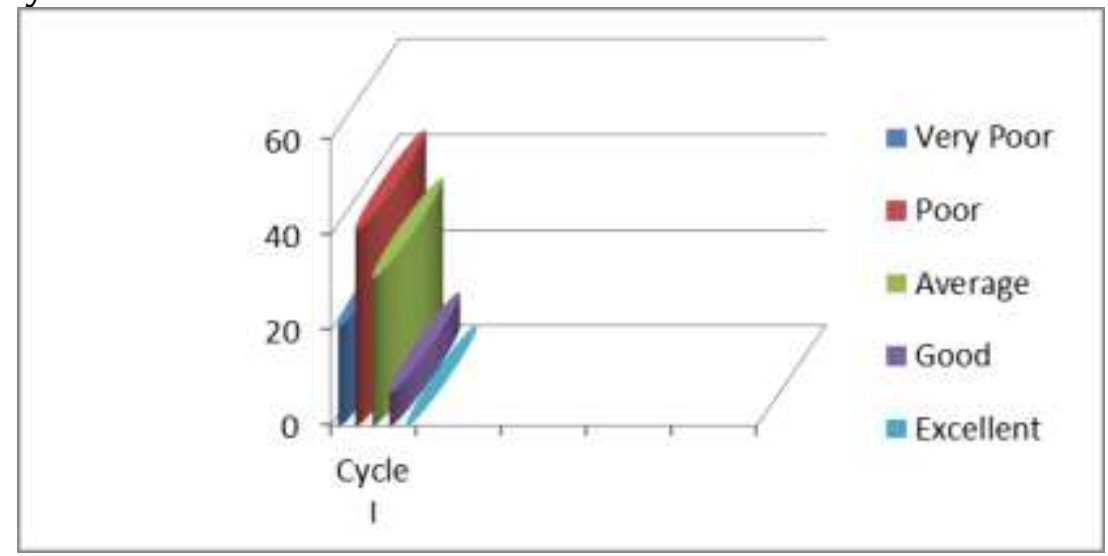

Figure I. Students' writing Score in Cycle I

From the figure above, the students' score is into percentages. The percentages can be seen from the following table:

\begin{tabular}{llll}
\hline \multirow{2}{*}{ Interval } & Qualification & \multicolumn{2}{c}{ Cycle I } \\
\cline { 3 - 4 } & & $\begin{array}{c}\text { Number of } \\
\text { Students }\end{array}$ & Percentages \\
\hline $85-100$ & Excellent & - & $0 \%$ \\
$71-84$ & Very good & 3 & $7 \%$ \\
$60-70$ & Good & 13 & $31 \%$ \\
$40-59$ & Low & 17 & $41 \%$ \\
$0-39$ & Failed & 9 & $21 \%$ \\
\hline
\end{tabular}

Table 1: The Distribution of Students' writing in Cycle I

From the table above, there is improvement in students' writing than in cycle I. The data shows that $0 \%$ of students are excellent categories, $7 \%$ 
are very good, $31 \%$ are good categories, $41 \%$ are low categories and $21 \%$ are failed. Based on the evaluation and reflection, researcher and collaborator conclude that there is improvement in students' writing. However, researcher feels that it is important to increase students' writing because indicator of success has not been reached yet because some of students it because of the problems such as their lack of understanding about the text, unfamiliar word and sentences, and lack of vocabularies. Besides that, the teaching method that applied before was not interest. Therefore, researcher and collaborator need to do action again.

\section{b. Cycle II}

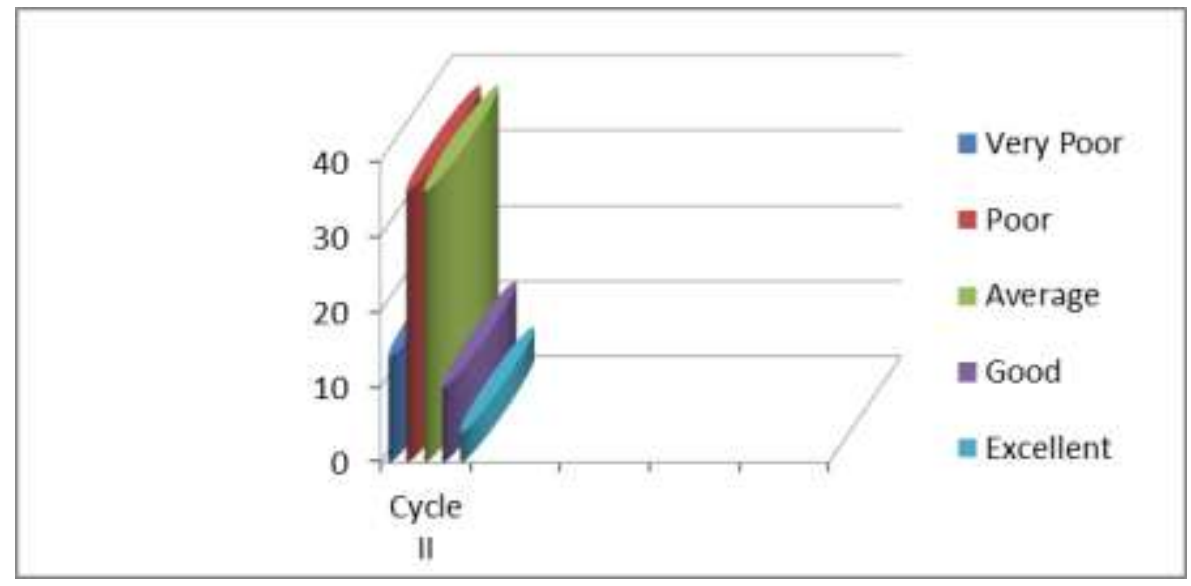

Figure II. Students' writing Score in Cycle II

From the figure above, the researcher collect the students' writing score into percentages. It can be seen from the following table:

\begin{tabular}{llll}
\hline \multirow{2}{*}{ Interval } & \multirow{2}{*}{ Qualification } & \multicolumn{2}{c}{ Cycle II } \\
\cline { 3 - 4 } & & Sumber of & Percentages \\
\hline $85-100$ & Excellent & 2 & $4 \%$ \\
$71-84$ & Very good & 4 & $10 \%$ \\
$60-70$ & Good & 15 & $36 \%$ \\
$40-59$ & Low & 15 & $36 \%$ \\
$0-39$ & Failed & 6 & $14 \%$ \\
\hline
\end{tabular}

Table 2. The Distribution of Students' writing in Cycle II

From the table above, it can be seen that students' writing ability increase in teaching writing activity. It shows that $4 \%$ of student total 
numbers are categories excellent, $10 \%$ are very good, 36\% are good, 36\% are low and $14 \%$ are failed categories.

From the data above, researcher feels that the indicator of success has not been reached yet because there are some problems in teaching writing activity such as mentioned in cycle I, even some students have been trying to minimize the problems. That is why, researcher and collaborator think that it is important to over comes the problems in order indicator of success can be reached. Therefore, it is needed to do next cycle.

\section{c. Cycle III 1}

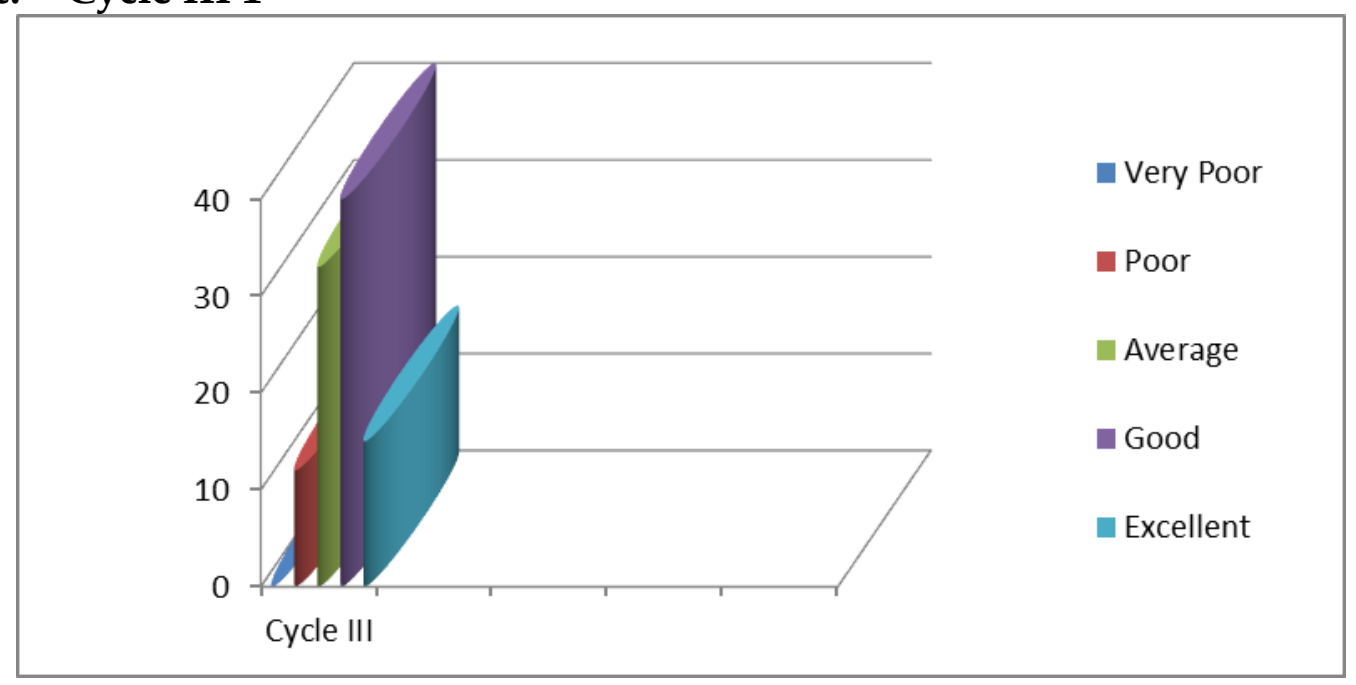

Figure III. Students' writing Score in Cycle III

From the figure above, the researcher collects the students' writing achievement into percentages. The percentages can be seen from the following table:

\begin{tabular}{llll}
\hline \multirow{2}{*}{ Interval } & Qualification & \multicolumn{2}{c}{ Cycle III } \\
\cline { 3 - 4 } & & Number of & Ptudents \\
\hline $85-100$ & Excellent & 6 & $12 \%$ \\
$71-84$ & Very good & 17 & $33 \%$ \\
$60-70$ & Good & 14 & $40 \%$ \\
$40-59$ & Low & 5 & $15 \%$ \\
$0-39$ & Failed & 0 & $0 \%$ \\
\hline
\end{tabular}

Table 3. The Distribution of Students' writing in Cycle III 
From table above, it can be concluded that any progrees on students' writing. It show that $12 \%$ students who are excellent categories, $33 \%$ are very good, $40 \%$ are good, $15 \%$ are low and $0 \%$ is failed.

From the data above, researcher see that most of students could decrease their problems in writing, but researcher feels that the indicator of success has been reached. Therefore, the researcher decided to stop the action.

\section{Discussion}

Based on the results which found by researcher in each cycles of this research, we could see that most of students were interested in learning English writing through Pictures media. They had good selvesconfidence to express their ideas in learning activity inside classroom, most of them could decrease their fears and rigidness to practice English skill in the form of writing, the frequency and percentage of students' writing ability were increased well in each cycles. In addition, picture media could motivate the students to be active and had a great participation in writing activity during teaching and learning process in classroom.

\section{CONCLUSION}

Method or technique is one of important things that must be applied during teaching and learning process in order the purpose of teaching can be reached and the students could enjoy the learning process without thinking that learning English is horrible subject. One of the method or media can be applied in teaching English writing is picture media because by applying the technique, teaching English writing can be more effective, and it is able to improve students' writing ability, especially in Mts N 01 of Bengkulu city. 


\section{E. REFERENCES}

Agustriana, N. (2019). PENGARUH METODE EDUTAINMENT DAN IDENTITAS DIRI TERHADAP KETERAMPILAN SOSIAL ANAK. Al-Fitrah, 1(2), 216-228. Retrieved from http://ejournal.iainbengkulu.ac.id/index.php/alfitrah/article/view $/ 1517$

Amin, A., Wiwinda, W., Alimni, A., \& Yulyana, R. (2018). Pengembangan Materi Pendidikan Agama Islam Berbasis Model Pembelajaran Inquiry Training Untuk Karakter Kejujuran Siswa Sekolah Menengah Pertama. At-Ta'lim: Media Informasi Pendidikan Islam, 17(1). Retrieved from http://ejournal.iainbengkulu.ac.id/index.php/attalim/article/view $/ 1418$

Anderson, A and Anderson, K. (1997). Text types in English 2. South Yara: macmillan Education Australia PTY LTD

Emilia. (2010). Teaching writing : developing critical learners. Bandung : rizqi. Hal 107

Gerlach, v.s., Ely, D.P (1980). Teaching and Media: A systematic Approach (2nd Ed). New jersey : prentice

Haris, David P. (1969). Testing English as a Second Language, washington DC: Georetown University

Harmer. (2007). The Practice of English Language Teachin, (Essex: Pearson Education Limited

Hatcher, S. (1987). Teaching with objects and photograph. Maxico. Mathers musium of word culture

Heaton, J. B. (1989). Writing English Language Test. New York: Longman Group UK Limited

Knaap, P. (2005). Genre, text, and grammar .Sydney: University of New South Wales.

Kurniah, N., Andreswari, D., \& Kusumah, R. G. T. (2019). Achievement of Development on Early Childhood Based on National Education Standard. In Proceedings of the International Conference on Educational 
Sciences and Teacher Profession (ICETeP 2018) (pp. 351-354). Paris, France: Atlantis Press. https:/ / doi.org/10.2991/icetep-18.2019.82

Kusumah, R. G. T. (2019). Peningkatan Kemampuan Berfikir Kritis Mahasiswa Tadris IPA Melalui Pendekatan Saintifik Pada Mata kuliah IPA Terpadu. IJIS Edu: Indonesian Journal of Integrated Science Education, 1(1), 71-84. Retrieved from http:/ / ejournal.iainbengkulu.ac.id/index.php/ijisedu/article/view /1762

Kusumah, R. G. T., \& Munandar, A. (2017). Analysis Of The Relationship Between Self Efficacy And Healthy Living Conciousness Toward Science Learning Outcome. EDUSAINS, 9(2), 132-138. https://doi.org/10.15408/ES.V9I2.2183

Oller, J. W. (1979). Language Testing at School. London: Longman Group Ltd.

Sapri, J., Agustriana, N., \& Kusumah, R. G. T. (2019). The Application of Dick and Carey Learning Design toward Student's Independence and Learning Outcome. In Proceedings of the International Conference on Educational Sciences and Teacher Profession (ICETeP 2018) (pp. 218222). Paris, France: Atlantis Press. https://doi.org/10.2991/icetep18.2019 .53

Siahaan S. \& Shinoda, K. (2008). Generic text structure. Yogyakarta: Graha Ilmu.

Wadirman, A. (2008). English in Focus for Grade VIII Junior High School (SMP/MTs).Jakarta: Pusat Perbukuan Departemen Pendidikan Nasional.

Walid, A., Putra, E. P., \& Asiyah. (2019). Pembelajaran Biologi Menggunakan Problem Solving Disertai Diagram Tree Untuk Memberdayakan Kemampuan Berpikir Logis Dan Kemampuan Menafsirkan Siswa. IJIS Edu: Indonesian Journal of Integrated Science Education, 1(1), 1-6. Retrieved from http:/ / ejournal.iainbengkulu.ac.id/index.php/ijisedu 